\title{
Pengaruh Content Marketing dan Dukungan Influencer terhadap Minat Beli Konsumen pada Produk Fashion
}

\section{Rachmi Oktora Citra Rahayu*, Hendrati Dwi Mulyaningsih}

Prodi Manajemen, Fakultas Ekonomi dan Bisnis, Universitas Islam Bandung, Indonesia.

*rahmioktora1@gmail.com,hendrati.dwi@gmail.com

\begin{abstract}
This research focuses on the application of Content Marketing and Influencers to Consumer Purchase Interest in Fashion Products. The purpose of this study is to determine how much influence Content Marketing and Influencers have on Puru Kambera's consumer buying interest. This research is included in the type of quantitative research using a correlation approach. The data collection technique in this study was carried out through the distribution of questionnaires. The object of this research is the permanent consumers of Puru Kambera as many as 250 people and narrowed down in the number of samples as many as 155 consumers. The sampling technique used in this research is simple random sampling, where the researcher determines the sample randomly. The data analysis used is descriptive and statistical analysis using multiple linear regression analysis, F test and T test. The results of this study indicate that the Content Marketing variable partially has a significant effect on Purchase Interest and the Influencer variable partially has a significant effect on Purchase Interest. And simultaneously the variables of Content Marketing and Influencer have a significant effect on consumer buying interest at Puru Kambera.
\end{abstract}

Keywords: Content Marketing, Influencer, Purchase Intention.

Abstrak. . Penelitian ini berfokus pada penerapan Content Marketing dan Influencer terhadap Minat Beli konsumen pada Produk Fashion. Tujuan penelitian ini untuk mengetahui seberapa besar pengaruh Content Marketing dan Influencer terhadap Minat Beli konsumen Puru Kambera. Penelitian ini termasuk kedalam jenis penelitian kuantitatif dengan menggunakan pendekatan korelasi. Teknik pengumpulan data dalam penelitian ini dilakukan melalui penyebaran angket. Objek penelitian ini adalah konsumen tetap Puru Kambera sebanyak 250 orang dan dikerucutkan dalam jumlah sampel sebanyak 155 orang konsumen. Teknik sampling yang digunakan dalam penelitian ini adalah simple random sampling, dimana peneliti menentukan sampel secara acak. Analisis data yang digunakan adalah analisis deksriptif dan statistik yaitu dengan menggunakan analisis regresi linier berganda, uji F dan uji T. Hasil dari penelitian ini menunjukkan bahwa variabel Content Marketing secara parsial berpengaruh signifikan terhadap Minat Beli dan variabel Influencer secara parsial berpengaruh signifikan terhadap Minat Beli. Dan secara simultan variabel Content Marketing dan Influencer berpengaruh signifikan terhadap Minat Beli konsumen pada Puru Kambera.

Kata Kunci: Content Marketing, Influencer, Minat Beli. 


\section{A. Pendahuluan}

Pandemi Covid-19 yang telah terjadi sejak tahun 2020 lalu membuat perekonomian di Indonesia mengalami krisis berkepanjangan. Penerapan kebijakan pembatasan kegiatan masyarakat atau PPKM membuat para pebisnis mengalami kerugian yang cukup besar karena mereka diberikan pembatasan ruang gerak untuk menjual produknya.

Guna mengembangkan strategi pemasaran dalam bisnis yang sedang dijalankan di era pandemi Covid-19 ini, maka para pelaku bisnis dapat menggunakan digital marketing dimana salah satunya adalah dengan menggunakan sosial media. Sosial media dianggap sebagai salah satu alat yang baik untuk dipakai dalam mempromosikan dan mengembangkan produk secara cepat terutama di situasi pandemi seperti sekarang ini.

Sosial media merupakan sarana bagi konsumen untuk berbagi informasi teks, gambar, audio dan video dengan satu sama lain dan dengan perusahaan dan sebaliknya (Kotler \& Keller, 2016). Berdasarkan laporan data dari Hootsuite (We are Social) yang berjudul Digital 2021 : The Latest Insight Into The State of Digital, disebutkan bahwa dari total 274,9 juta penduduk Indonesia, 170 juta diantaranya telah menggunakan sosial media dengan sebagian besar platform yang cukup sering digunakan adalah Instagram.

Banyaknya fitur yang disediakan oleh instagram membuat para pebisnis saling berkompetisi membuat konten yang lebih menarik untuk ditampilkan dalam memasarkan produknya. Menurut (Lammenett, 2019) content marketing adalah tentang memberikan nilai. Hal ini dapat dilakukan dengan konten yang informatif, menasihati dan menghibur melalui teks, gambar, video atau podcast.

Selain content marketing, salah satu faktor yang dapat membuat para pelaku bisnis mendapat keberhasilan dalam melakukan pemasaran melalui sosial media adalah dengan menggunakan influencer. Pengertian influencer sendiri merupakan seorang pendukung iklan yang disukai dan dihormati oleh sejumlah orang atau konsumen serta mampu mempengaruhi secara positif tindakan dan perilaku seorang konsumen. (Andrews \& Shimp , 2018).

Berdasarkan uraian diatas, fenomena tersebut berkaitan dengan variabel content marketing dan dukungan influencer. Dengan demikian, maka penulis menentukan ini menjadi variabel (X1) dan (X2) yang akan diteliti.

Selanjutnya hal yang berkaitan dengan content marketing dan dukungan influencer adalah minat beli konsumen. Minat beli adalah seberapa besar kemungkinan konsumen membeli suatu merek dan jasa atau seberapa besar kemungkinan konsumen untuk berpindah dari satu merek ke merek lainnya. Bila manfaat yang lebih besar dibandingkan pengorbanan untuk mendapatkannya maka dorongan untuk membeli semakin tinggi. (Kotler \& Keller, 2016).

Penelitian ini dilakukan pada Official Account Instagram Puru Kambera yang dimana setelah dilakukan observasi telah terjadi penurunan penjualan pada tahun 2020 terutama ketika awal pandemi Covid-19 yang terjadi di bulan Maret. Penurunan tersebut diduga karena Puru Kambera belum optimal dan rutin dalam memberikan Content Marketing di sosial media Instagram yang memuat informasi seputar produk. Selain itu, Puru Kambera juga belum dapat bekerjasama dengan para influencer yang telah banyak dikenal oleh banyak masyarakat sehingga membuat konsumen kurang percaya dan tidak berminat untuk membeli produk Puru Kambera.

Berdasarkan latar belakang yang telah diuraikan, maka perumusan masalah dalam penelitian ini sebagai berikut:

1. Untuk mengetahui penerapan content marketing pada instagram Puru Kambera.

2. Untuk mengetahui peran influencer pada instagram Puru Kambera.

3. Untuk mengetahui minat beli konsumen pada produk Puru Kambera.

4. Untuk mengetahui pengaruh content marketing dalam meningkatkan minat beli konsumen pada produk Puru Kambera.

5. Untuk mengetahui pengaruh influencer dalam meningkatkan minat beli konsumen pada produk Puru Kambera.

Untuk mengetahui pengaruh content marketing dan influencer terhadap minat beli konsumen pada produk Puru Kambera. Selanjutnya, berdasarkan rumusan masalah yang ada, maka tujuan dalam penelitian ini diuraikan dalam pokok-pokok berikut: 
1. Untuk mengetahui penerapan content marketing pada instagram Puru Kambera.

2. Untuk mengetahui peran influencer pada instagram Puru Kambera.

3. Untuk mengetahui minat beli konsumen pada produk Puru Kambera.

4. Untuk mengetahui pengaruh content marketing dalam meningkatkan minat beli konsumen pada produk Puru Kambera.

5. Untuk mengetahui pengaruh influencer dalam meningkatkan minat beli konsumen pada produk Puru Kambera.

6. Untuk mengetahui pengaruh content marketing dan influencer terhadap minat beli konsumen pada produk Puru Kambera.

\section{B. Metodologi Penelitian}

Peneliti menggunakan metode teknik analisis korelasional dengan menggunakan pendekatan kuantitatif. Populasi yang dipilih dalam penelitian ini adalah konsumen tetap Puru Kambera yang berjumlah 250 orang konsumen.

Dengan teknik pengambilan sampel yaitu Simple Random Sampling diperoleh jumlah sampel penelitian sebanyak 155 orang konsumen. Teknik pengumpulan data yang digunakan dalam penelitian ini adalah kuesioner, wawancara, observasi, dan studi pustaka. Adapun teknik analisis data yang digunakan dalam penelitian ini adalah teknis analisis deskriptif dan analisis verifikatif.

\section{Hasil Penelitian dan Pembahasan}

\section{Uji Validitas}

Untuk mengetahui validitas setiap item pertanyaan yang termuat pada kuesioner,peneliti menggunakan SPSS versi 25 dengan rTabel dalam penelitian ini adalah 0,1577 (df $=153$ dan $\alpha$ $=5 \%)$. Berikut ini adalah table hasil uji validitas dalam penelitian ini.

Tabel 1. Uji Validitas Data Penelitian Variabel Content Marketing (X1)

\begin{tabular}{|c|c|c|c|c|}
\hline Variabel & $\begin{array}{l}\text { Item Butir } \\
\text { Pertanyaan }\end{array}$ & $\begin{array}{l}\text { Nilai Korelasi } \\
\text { (rHitung) }\end{array}$ & $\begin{array}{l}\text { Nilai Batas } \\
\text { (rTabel) }\end{array}$ & Keterangan \\
\hline \multirow{24}{*}{$\begin{array}{c}\text { Content } \\
\text { Marketing }\end{array}$} & $\mathrm{P} 1$ & 0,511 & 0,1577 & Valid \\
\hline & $\mathrm{P} 2$ & 0,462 & 0,1577 & Valid \\
\hline & P3 & 0,611 & 0,1577 & Valid \\
\hline & P4 & 0,561 & 0,1577 & Valid \\
\hline & P5 & 0,482 & 0,1577 & Valid \\
\hline & P6 & 0,633 & 0,1577 & Valid \\
\hline & $\mathrm{P} 7$ & 0,494 & 0,1577 & Valid \\
\hline & P8 & 0,707 & 0,1577 & Valid \\
\hline & P9 & 0,659 & 0,1577 & Valid \\
\hline & P10 & 0,684 & 0,1577 & Valid \\
\hline & P11 & 0,691 & 0,1577 & Valid \\
\hline & P12 & 0,666 & 0,1577 & Valid \\
\hline & P13 & 0,668 & 0,1577 & Valid \\
\hline & P14 & 0,736 & 0,1577 & Valid \\
\hline & P15 & 0,683 & 0,1577 & Valid \\
\hline & P16 & 0,674 & 0,1577 & Valid \\
\hline & P17 & 0,684 & 0,1577 & Valid \\
\hline & P18 & 0,693 & 0,1577 & Valid \\
\hline & P19 & 0,702 & 0,1577 & Valid \\
\hline & P20 & 0,756 & 0,1577 & Valid \\
\hline & $\mathrm{P} 21$ & 0,629 & 0,1577 & Valid \\
\hline & P22 & 0,681 & 0,1577 & Valid \\
\hline & P23 & 0,660 & 0,1577 & Valid \\
\hline & P24 & 0,695 & 0,1577 & Valid \\
\hline
\end{tabular}




\begin{tabular}{|l|l|l|l|}
\hline P25 & 0,791 & 0,1577 & Valid \\
& & & \\
\hline P26 & 0,706 & 0,1577 & Valid \\
\hline P27 & 0,739 & 0,1577 & Valid \\
\hline P28 & 0,667 & 0,1577 & Valid \\
\hline P29 & 0,587 & 0,1577 & Valid \\
\hline P30 & 0,640 & 0,1577 & Valid \\
\hline P31 & 0,660 & 0,1577 & Valid \\
\hline P32 & 0,674 & 0,1577 & Valid \\
\hline P33 & 0,637 & 0,1577 & Valid \\
\hline P34 & 0,652 & 0,1577 & Valid \\
\hline P35 & 0,326 & 0,1577 & Valid \\
\hline P36 & 0,596 & 0,1577 & Valid \\
\hline P37 & 0,448 & 0,1577 & Valid \\
\hline P38 & 0,531 & 0,1577 & Valid \\
\hline
\end{tabular}

Tabel 2. Uji Validitas Data Penelitian Variabel Influencer (X2)

\begin{tabular}{|c|c|c|c|c|}
\hline Variabel & $\begin{array}{c}\text { Item Butir } \\
\text { Pertanyaan }\end{array}$ & $\begin{array}{c}\text { Nilai Korelasi } \\
\text { (rHitung) }\end{array}$ & $\begin{array}{c}\text { Nilai Batas } \\
\text { (rTabel) }\end{array}$ & Keterangan \\
\hline \multirow{6}{*}{ P1 } & 0,740 & 0,1577 & Valid \\
\cline { 2 - 5 } & P2 & 0,757 & 0,1577 & Valid \\
\cline { 2 - 5 } & P3 & 0,743 & 0,1577 & Valid \\
\cline { 2 - 5 } & P4 & 0,757 & 0,1577 & Valid \\
\cline { 2 - 5 } & P5 & 0,768 & 0,1577 & Valid \\
\cline { 2 - 5 } & P6 & 0,789 & 0,1577 & Valid \\
\cline { 2 - 5 } & P7 & 0,762 & 0,1577 & Valid \\
\cline { 2 - 5 } & P8 & 0,797 & 0,1577 & Valid \\
\cline { 2 - 5 } & P9 & 0,775 & 0,1577 & Valid \\
\cline { 2 - 5 } & P10 & 0,650 & 0,1577 & Valid \\
\cline { 2 - 5 } & P11 & 0,801 & 0,1577 & Valid \\
\cline { 2 - 5 } & P12 & 0,814 & 0,1577 & Valid \\
\cline { 2 - 5 } & P13 & 0,624 & 0,1577 & Valid \\
\cline { 2 - 5 } & P14 & 0,653 & 0,1577 & Valid \\
\cline { 2 - 5 } & P15 & 0,529 & 0,1577 & Valid \\
\cline { 2 - 5 } & P16 & 0,589 & 0,1577 & Valid \\
\cline { 2 - 5 } & P17 & 0,634 & 0,1577 & Valid \\
\cline { 2 - 5 } & P18 & 0,787 & 0,1577 & Valid \\
\cline { 2 - 5 } & P19 & 0,588 & 0,1577 & Valid \\
\cline { 2 - 5 } & P20 & 0,653 & 0,1577 & Valid \\
\hline
\end{tabular}

Tabel 3. Uji Validitas Data Penelitian Variabel Minat Beli (Y)

\begin{tabular}{|c|c|c|c|c|}
\hline Variabel & $\begin{array}{c}\text { Item Butir } \\
\text { Pertanyaan }\end{array}$ & $\begin{array}{c}\text { Nilai Korelasi } \\
\text { (rHitung) }\end{array}$ & $\begin{array}{c}\text { Nilai Batas } \\
\text { (rTabel) }\end{array}$ & Keterangan \\
\hline \multirow{6}{*}{} & P1 & 0,414 & 0,1577 & Valid \\
\cline { 2 - 5 } & P2 & 0,636 & 0,1577 & Valid \\
\cline { 2 - 5 } & P3 & 0,825 & 0,1577 & Valid \\
\cline { 2 - 5 } & P4 & 0,809 & 0,1577 & Valid \\
\hline
\end{tabular}


Minat Beli

\begin{tabular}{|c|c|c|c|}
\hline P5 & 0,854 & 0,1577 & Valid \\
\hline P6 & 0,827 & 0,1577 & Valid \\
\hline P7 & 0,675 & 0,1577 & Valid \\
\hline P8 & 0,635 & 0,1577 & Valid \\
\hline P9 & 0,776 & 0,1577 & Valid \\
\hline P10 & 0,755 & 0,1577 & Valid \\
\hline
\end{tabular}

Berdasarkan tabel diatas diketahui bahwa semua variabel memiliki nilai korelasidiatas 0,1577 sehingga semua item pernyataan tersebut dikatakan valid dan bisa digunakan untuk melanjutkan analisis selanjutnya. Dari tabel diatas dapat ditafsirkan bahwa setiap pernyataan yang ada dalam kuesioner dapat dimengerti oleh responden yangmenjawab karena terbukti setiap nilai korelasi lebih besar dari nilai batas yang ditentukan.

Uji Reliabilitas

Tabel 4. Uji Reliabilitas

\begin{tabular}{|l|c|c|c|}
\hline & $\begin{array}{c}\text { Cronbach } \\
\text { Alpha }\end{array}$ & $\begin{array}{c}\text { Nilai Batas } \\
\text { (rTabel) }\end{array}$ & Keterangan \\
\hline Content Marketing (X1) & 0,956 & 0,70 & Reliabel \\
\hline Influencer $(\mathrm{X} 2)$ & 0,944 & 0,70 & Reliabel \\
\hline Minat Beli $(\mathrm{Y})$ & 0,895 & 0,70 & Reliabel \\
\hline
\end{tabular}

Berdasarkan hasil uji reliabilitas diatas, dapat disimpulkan bahwa uji reliabilitas variabel; X1, X2, dan Y itu konsisten karena variabel X1 memiliki alpha yang lebih besardari rTabel yaitu 0,956>0,70, untuk variabel X2 memiliki alpha yang lebih besar dari rTabel yaitu $0,944>0,70$, begitu pula variabel Y memiliki alpha yang lebih besar dari rTabel yaitu 0,895> 0,70 . Hal ini meyakinkan bahwa kuesionar yang dibuat benar-benarbaik dalam mengukur gejala dan menghasilkan data yang valid.

\section{Analisis Deskriptif}

Tabel 5. Tanggapan Responden Terhadap Content Marketing Puru Kambera

\begin{tabular}{|c|l|c|c|c|}
\hline NO & Pertanyaan & Skor & Mean & Klasifikasi \\
\hline 1 & Pertanyaan 1 & 669 & 4,32 & Sangat Baik \\
\hline 2 & Pertanyaan 2 & 658 & 4,24 & Sangat Baik \\
\hline 3 & Pertanyaan 3 & 651 & 4,20 & Sangat Baik \\
\hline 4 & Pertanyaan 4 & 664 & 4,28 & Sangat Baik \\
\hline 5 & Pertanyaan 5 & 675 & 4,35 & Sangat Baik \\
\hline 6 & Pertanyaan 6 & 635 & 4,09 & Baik \\
\hline 7 & Pertanyaan 7 & 618 & 3,98 & Baik \\
\hline 8 & Pertanyaan 8 & 645 & 4,16 & Baik \\
\hline 9 & Pertanyaan 9 & 650 & 4,19 & Baik \\
\hline 10 & Pertanyaan 10 & 658 & 4,24 & Sangat Baik \\
\hline 11 & Pertanyaan 11 & 663 & 3,92 & Sangat Baik \\
\hline 12 & Pertanyaan 12 & 609 & 4,01 & Baik \\
\hline 13 & Pertanyaan 13 & 621 & 4,20 & Baik \\
\hline 14 & Pertanyaan 14 & 651 & 4,24 & Sangat Baik \\
\hline 15 & Pertanyaan 15 & 657 & 4,35 & Sangat Baik \\
\hline 16 & Pertanyaan 16 & 675 & 4,32 & Sangat Baik \\
\hline 17 & Pertanyaan 17 & 669 & 4,04 & Baik \\
\hline 18 & Pertanyaan 18 & 646 & & Baik \\
\hline 19 & Pertanyaan 19 & 627 & & \\
\hline
\end{tabular}




\begin{tabular}{|l|l|l|c|c|}
\hline 20 & Pertanyaan 20 & 640 & 4,13 & Baik \\
\hline 21 & Pertanyaan 21 & 649 & 4,19 & Baik \\
\hline 22 & Pertanyaan 22 & 674 & 4,34 & Sangat Baik \\
\hline 23 & Pertanyaan 23 & 616 & 3,97 & Baik \\
\hline 24 & Pertanyaan 24 & 632 & 4,08 & Baik \\
\hline 25 & Pertanyaan 25 & 649 & 4,19 & Baik \\
\hline 26 & Pertanyaan 26 & 619 & 3,99 & Baik \\
\hline 27 & Pertanyaan 27 & 660 & 4,26 & Sangat Baik \\
\hline 28 & Pertanyaan 28 & 653 & 4,21 & Sangat Baik \\
\hline 29 & Pertanyaan 29 & 671 & 4,33 & Sangat Baik \\
\hline 30 & Pertanyaan 30 & 660 & 4,26 & Sangat Baik \\
\hline 31 & Pertanyaan 31 & 648 & 4,18 & Baik \\
\hline 32 & Pertanyaan 32 & 660 & 4,26 & Sangat Baik \\
\hline 33 & Pertanyaan 33 & 613 & 3,95 & Baik \\
\hline 34 & Pertanyaan 34 & 606 & 3,84 & Baik \\
\hline 35 & Pertanyaan 35 & 539 & 3,91 & Baik \\
\hline 36 & Pertanyaan 36 & 574 & 3,70 & Baik \\
\hline 37 & Pertanyaan 37 & 582 & 3,75 & Baik \\
\hline 38 & Pertanyaan 38 & 580 & 3,74 & Baik \\
\hline & Total & 24.266 & 156,86 & Baik \\
\cline { 2 - 4 } & Rata-Rata & 639 & 4,13 & \\
\hline
\end{tabular}

Dari tabel diatas dapat disimpulkan bahwa tanggapan responden mengenai variabel Content Marketing menghasilkan rata-rata dari seluruh indikator sebesar 4,13 yang berada dalam kategori baik karena berada dalam interval 527 - 651. Artinya, secara keseluruhan responden menilai bahwa Content Marketing yang diberikan oleh Puru Kambera dirasakan baik.

Tabel 6. Tanggapan Responden Mengenai Influencer Puru Kambera

\begin{tabular}{|c|l|c|c|c|}
\hline NO & \multicolumn{1}{|c|}{ Pertanyaan } & Skor & Mean & Klasifikasi \\
\hline 1 & Pertanyaan 1 & 648 & 4,18 & Baik \\
\hline 2 & Pertanyaan 2 & 656 & 4,23 & Sangat Baik \\
\hline 3 & Pertanyaan 3 & 636 & 4,10 & Baik \\
\hline 4 & Pertanyaan 4 & 627 & 4,04 & Baik \\
\hline 5 & Pertanyaan 5 & 633 & 4,08 & Baik \\
\hline 6 & Pertanyaan 6 & 646 & 4,16 & Baik \\
\hline 7 & Pertanyaan 7 & 650 & 4,19 & Baik \\
\hline 8 & Pertanyaan 8 & 647 & 4,17 & Baik \\
\hline 9 & Pertanyaan 9 & 657 & 4,24 & Sangat Baik \\
\hline 10 & Pertanyaan 10 & 646 & 4,16 & Baik \\
\hline 11 & Pertanyaan 11 & 644 & 4,15 & Baik \\
\hline 12 & Pertanyaan 12 & 653 & 4,21 & Sangat Baik \\
\hline 13 & Pertanyaan 13 & 628 & 4,05 & Baik \\
\hline 14 & Pertanyaan 14 & 620 & 4,00 & Baik \\
\hline 15 & Pertanyaan 15 & 609 & 3,93 & Baik \\
\hline 16 & Pertanyaan 16 & 629 & 4,06 & Baik \\
\hline 17 & Pertanyaan 17 & 664 & 4,28 & Sangat Baik \\
\hline 18 & Pertanyaan 18 & 653 & 4,21 & Sangat Baik \\
\hline 19 & Pertanyaan 19 & 617 & 3,98 & Baik \\
\hline 20 & Pertanyaan 20 & 604 & 3,89 & Baik \\
\hline & Total & 12.767 & 82,31 & Baik \\
\hline & Rata-Rata & 638 & 4,16 & Bain \\
\hline
\end{tabular}

Dari tabel diatas dapat disimpulkan bahwa tanggapan responden mengenai variabel 
influencer menghasilkan rata-rata dari seluruh indikator sebesar 4,16 yang berada dalam kategori baik karena berada dalam interval 527 - 651. Artinya, secarakeseluruhan responden menilai bahwa influencer yang bekerjasama dengan Puru Kambera telah melakukan tugasnya dengan baik.

Tabel 7. Tanggapan Responden Mengenai Minat Beli pada produk Puru Kambera

\begin{tabular}{|c|c|c|c|c|}
\hline NO & Pertanyaan & Skor & Mean & Klasifikasi \\
\hline 1 & Pertanyaan 1 & 584 & 3,76 & Baik \\
\hline 2 & Pertanyaan 2 & 616 & 3,97 & Baik \\
\hline 3 & Pertanyaan 3 & 594 & 3,83 & Baik \\
\hline 4 & Pertanyaan 4 & 571 & 3,68 & Baik \\
\hline 5 & Pertanyaan 5 & 595 & 3,83 & Baik \\
\hline 6 & Pertanyaan 6 & 564 & 3,63 & Baik \\
\hline 7 & Pertanyaan 7 & 537 & 3,46 & Baik \\
\hline 8 & Pertanyaan 8 & 462 & 2,98 & Cukup \\
\hline 9 & Pertanyaan 9 & 611 & 3,94 & Baik \\
\hline 10 & Pertanyaan 10 & 620 & 4,00 & Baik \\
\hline & Total & 5.754 & 37,08 & \multirow[t]{2}{*}{ Baik } \\
\hline & Rata-Rata & 575 & 3,71 & \\
\hline
\end{tabular}

Dari tabel diatas dapat disimpulkan bahwa tanggapan responden mengenai variabel Minat Beli menghasilkan rata-rata dari seluruh indikator sebesar 3,71 yang berada dalam kategori baik karena berada dalam interval 527 - 651. Artinya, secarakeseluruhan responden menilai bahwa Minat Beli pada produk Puru Kamberadirasakan baik.

Uji Hipotesis

Tabel 8. Uji Koefisien Korelasi (r)

\begin{tabular}{|c|c|c|c|c|}
\hline \multicolumn{5}{|c|}{ Correlation } \\
\hline & & $\begin{array}{l}\text { Content } \\
\text { Marketing } \\
\text { (X1) }\end{array}$ & $\begin{array}{l}\text { Influencer } \\
\text { (X2) }\end{array}$ & $\begin{array}{l}\text { Minat Beli } \\
\text { (Y) }\end{array}$ \\
\hline \multirow{3}{*}{$\begin{array}{l}\text { Content } \\
\text { Marketing } \\
\text { (X1) }\end{array}$} & Pearson Correlation & 1 & $.735 * *$ & $.688 * *$ \\
\hline & Sig. (2-tailed) & & .000 & .000 \\
\hline & $\mathrm{N}$ & 155 & 155 & 155 \\
\hline \multirow{3}{*}{$\begin{array}{l}\text { Influencer } \\
\text { (X2) }\end{array}$} & Pearson Correlation & $.735^{* *}$ & 1 & $.624 * *$ \\
\hline & Sig. (2-tailed) & .000 & & .000 \\
\hline & $\mathrm{N}$ & 155 & 155 & 155 \\
\hline \multirow{3}{*}{$\begin{array}{l}\text { Minat Beli } \\
\text { (Y) }\end{array}$} & Pearson Correlation & $.688 * *$ & $.624 * *$ & 1 \\
\hline & Sig. (2-tailed) & .000 & .000 & \\
\hline & $\mathrm{N}$ & 155 & 155 & 155 \\
\hline
\end{tabular}

Berdasarkan hasil perhitungan yang telah dilakukan, maka didapatkan koefisiensi antara variabel Content Marketing (X1) dengan Minat Beli (Y) sebesar $r=0,688$. Dari tabel interprestasi koefisien korelasi terlihat bahwa hasil korelasi tersebut berada pada interval 0,600,799 yang berarti terdapat hubungan yang kuat antara variabel Content Marketing (X1) dengan Minat Beli (Y).

Kemudian, didapatkan koefisiensi antara variabel Influencer (X2) dengan MinatBeli (Y) sebesar $\mathrm{r}=0,624$. Dari tabel interprestasi koefisien korelasi terlihat bahwa hasilkorelasi tersebut berada pada interval 0,60-0,799 yang berarti bahwa terdapat hubungan yang kuat antara Influencer dengan Minat Beli (Y).

Tabel 9. Analisis Regresi Linier Berganda 


\begin{tabular}{|c|c|c|c|c|c|c|c|}
\hline \multicolumn{8}{|c|}{ Coefficients $^{\mathbf{a}}$} \\
\hline \multirow[t]{2}{*}{ Model } & \multicolumn{2}{|c|}{$\begin{array}{l}\text { Unstandardized } \\
\text { Coefficients }\end{array}$} & \multirow{2}{*}{$\begin{array}{c}\text { Standardized } \\
\text { Coefficients } \\
\text { Beta }\end{array}$} & \multirow[t]{2}{*}{$\mathrm{t}$} & \multirow[t]{2}{*}{ Sig. } & \multicolumn{2}{|c|}{$\begin{array}{l}\text { Collinearity } \\
\text { Statistics }\end{array}$} \\
\hline & B & Std. Error & & & & Tolerance & VIF \\
\hline (Constant) & .965 & 217 & & 4.442 & .000 & & \\
\hline $\begin{array}{l}\text { Content } \\
\text { Marketing }\end{array}$ & .280 & .047 & .499 & 5.914 & .000 & .459 & 2.178 \\
\hline Influencer & .174 & .057 & .257 & 3.045 & .003 & .459 & 2.178 \\
\hline
\end{tabular}

a. Dependent Variable: Minat Beli (Y)

Dari output diatas, maka dapat diketahui nilai konstanta dan nilai koefisien regresi sehingga dapat dibentuk persamaan regresi linier berganda sebagai berikut:

$\mathrm{Y}=0.965+0.280 \mathrm{X} 1+0.174 \mathrm{X} 2$

Keterangan:

1. $\mathrm{X} 1=$ Content Marketing

2. $\mathrm{X} 2=$ Influencer

3. $\mathrm{Y}=$ Minat Beli

Tabel 10. Koefisien Determinasi $(\mathrm{Kd})$

\begin{tabular}{|c|c|c|c|c|c|}
\hline \multicolumn{6}{|c|}{ Model Summary $^{\mathbf{b}}$} \\
\hline Model & $\mathrm{R}$ & $\mathrm{R}$ Square & $\begin{array}{c}\text { Adjusted R } \\
\text { Square }\end{array}$ & $\begin{array}{c}\text { Std. Error of } \\
\text { the Estimate }\end{array}$ & $\begin{array}{c}\text { Durbin- } \\
\text { Watson }\end{array}$ \\
\hline 1 & $.709^{\mathrm{a}}$ & .503 & .497 & .80151 & 1.544 \\
\hline
\end{tabular}

a. $\quad$ Predictors: (Constant), Influencer (X2), Content Marketing (X1)

b. Dependent Variable: Minat Beli $(\mathrm{Y})$

c.

Tabel 10 diatas menjelaskan besarnya nilai korelasi atau hubungan (r) yaitu 0,709. Dari output tersebut diperoleh koefisien determinasi (R Square) sebesar 0,503 yang mengandung pengertian bahwa pengaruh Content Marketing (X1) dan Influencer(X2) terhadap Minat Beli (Y) adalah sebesar 50,3\% sedangkan sisanya sebesar 49,7\% dipengaruhi oleh faktor dan variabel lainnya.

Tabel 11. Uji Signifikansi Parsial (Uji Statistik t)

\begin{tabular}{|c|c|c|c|c|c|c|c|}
\hline \multicolumn{8}{|c|}{ Coefficients $^{\mathbf{a}}$} \\
\hline \multirow[t]{2}{*}{ Model } & \multicolumn{2}{|c|}{$\begin{array}{c}\text { Unstandardized } \\
\text { Coefficients }\end{array}$} & \multirow{2}{*}{$\begin{array}{c}\text { Standardized } \\
\text { Coefficients } \\
\text { Beta }\end{array}$} & \multirow{2}{*}{$\mathrm{t}$} & \multirow{2}{*}{ Sig. } & \multicolumn{2}{|c|}{$\begin{array}{l}\text { Collinearity } \\
\text { Statistics }\end{array}$} \\
\hline & B & $\begin{array}{l}\text { Std. } \\
\text { Error }\end{array}$ & & & & Tolerance & VIF \\
\hline (Constant) & .965 & .217 & & 4.442 & .000 & & \\
\hline $\begin{array}{l}\text { Content } \\
\text { Marketing }\end{array}$ & .280 & .047 & .499 & 5.914 & .000 & .459 & 2.178 \\
\hline Influencer & .174 & .057 & .257 & 3.045 & .003 & .459 & 2.178 \\
\hline
\end{tabular}

Berdasarkan nilai signifikansi dari tabel coefficient diatas, maka dapat diperolehnilai signifikansi sebesar $0,000<0,05$. Sehingga dapat disimpulkan bahwa variabel Content Marketing (X1) berpengaruh terhadap variabel Minat Beli (Y). 


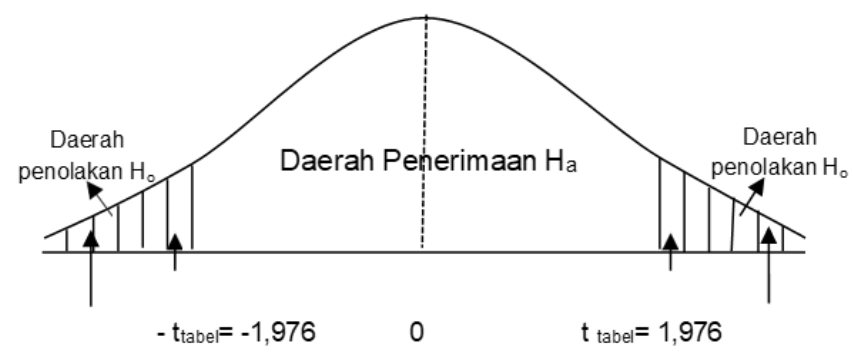

Gambar 1. Kurva Minat Beli

Berdasarkan nilai t, dapat diketahui bahwa tHitung sebesar 5,914 > tTabel sebesar 1,976. Gambar kurva yang diarsir diatas merupakan daerah Ho yang ditolak di kedua sisi, sedangkan bagian tengah kurva merupakan daerah Ha yang diterima. Sehingga dapat disimpulkan bahwa variabel Content Marketing (X1) berpengaruh secara signifikan terhadap variabel Minat Beli (Y) pada taraf $\alpha=5 \%$.

Kemudian, berdasarkan nilai signifikansi dari tabel coefficient diatas, maka dapat diperoleh nilai signifikansi sebesar $0,003<0,05$. Sehingga dapat disimpulkan bahwa variabel Influencer (X2) berpengaruh terhadap variabel Minat Beli (Y).

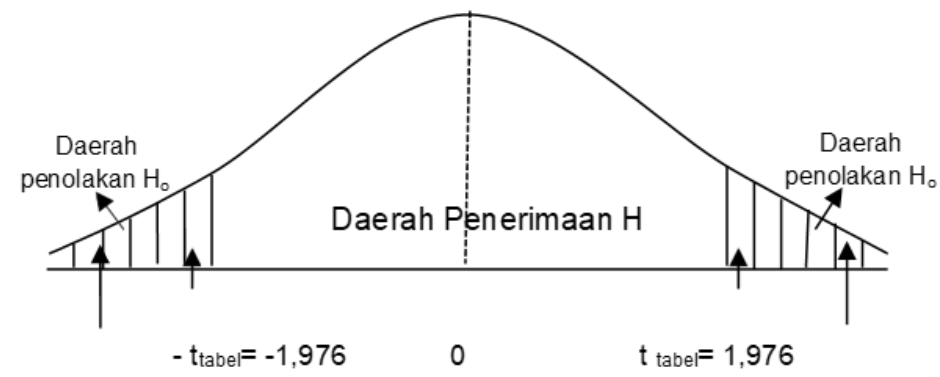

Gambar 2. Uji Statistik-t X2 terhadap Y

Berdasarkan nilai t, dapat diketahui bahwa tHitung sebesar 3,045 > tTabel sebesar 1,976. Gambar kurva yang diarsir diatas merupakan daerah Ho yang ditolak di kedua sisi, sedangkan bagian tengah kurva merupakan daerah Ha yang diterima. Sehingga dapat disimpulkan bahwa variabel Influencer (X2) berpengaruh secara signifikan terhadap variabel Minat Beli (Y) pada taraf $\alpha=5 \%$.

Tabel 12. Uji Signifikansi Simultan (Uji F)

\begin{tabular}{|c|c|c|c|c|c|c|}
\hline \multicolumn{7}{|c|}{ ANOVA $^{\mathbf{A}}$} \\
\hline & Model & $\begin{array}{l}\text { Sum of } \\
\text { Squares }\end{array}$ & $\mathrm{df}$ & $\begin{array}{l}\text { Mean } \\
\text { Square }\end{array}$ & $\mathrm{F}$ & Sig. \\
\hline \multirow[t]{3}{*}{1} & Regression & 98.968 & 2 & 49.484 & 77.029 & $.000^{\mathrm{b}}$ \\
\hline & Residual & 97.647 & 152 & .642 & & \\
\hline & Total & 196.615 & 154 & & & \\
\hline
\end{tabular}

Berdasarkan output diatas maka dapat diketahui bahwa nilai signifikansi untuk pengaruh Content Marketing (X1) dan Influencer (X2) terhadap Minat Beli (Y) adalah sebesar $0,000<0,05$ dan nilai $F_{\text {hitung }}$ sebear 77,029 $>$ dari $F_{\text {tabel }}$ sebesar3,06. Sehingga dapat disimpulkan bahwa H1 diterima yang berarti terdapat pengaruh antara Content Marketing (X1) dan Influencer (X2) secara simultan terhadap Minat Beli (Y) pada taraf $\alpha=5 \%$. 


\section{Kesimpulan}

Berdasarkan pembahasan dalam penelitian ini, peneliti menyimpulkan beberapa hasil penelitian sebagai berikut:

1. Content Marketing yang dilakukan oleh Puru Kambera dapat dikatakan "Baik" karena memiliki nilai 4,12 yang berada pada interval 3,40-4,20. Dari data tersebut dapat terlihat bahwa penilaian terbesar terdapat pada pernyataan "Puru Kambera mampu menyediakan konten yang dibuat dengan konsep foto,video, dan caption yang professional" dengan rata-rata nilai sebesar 4,36. Sedangkan pernyataan "Saya dipengaruhi oleh keluarga dalam mendapatkan konten sosial media" memiliki penilaian paling rendah dengan ratarata nilai sebesar 3,64.

2. Influencer yang bekerjasama dengan Puru Kambera dapat dikatakan memiliki peran yang "Baik" karena memiliki nilai 4,16 yang berada pada interval 3,40-4,20. Dari data tersebut dapat terlihat bahwa penilaian terbesar terdapat pada penyataan "Saya tertarik pada influencer yang banyak melakukan interaksi dengan para followers" dengan rata-rata nilai sebesar 4,28. Sedangkan pernyataan "Saya tertarik pada influencer yang memiliki tampilan fisik menarik" memiliki penilaian rendah dengan rata-rata nilai sebesar 3,93.

3. Minat beli konsumen pada produk Puru Kambera dapat dikatakan "Baik" karena memiliki nilai 3,70 yang berada pada interval 3,40-4,20. Tetapi, masih ada yang harus diperhatikan dari dimensi "Kecenderungan seseorang menjadikan produk sebagai prioritas utama" mengenai respon yang kurang baik yang terjadi karena produk Puru Kambera tidak dapat memenuhi sema kebutuhan konsumen.

4. Secara parsial terdapat pengaruh yang signifikan antara Content Marketing terhadap Minat beli dengan tingkat pengaruh yang "Kuat" dan arah hubungan yang positif. Hal tersebut dapat dilihat berdasarkan tabulasi data Uji t dengan nilai $t_{\text {Hitung }}$ sebesar 11,720 dan $t_{\text {Tabel }}$ sebesar 1,976. Dengan demikian maka $t_{\text {Hitung }} 11,720>t_{\text {Tabel }} 1,976$ dengan signifikansi 0,000 < 0,05 maka dari itu H0 ditolak dan Ha diterima.

5. Secara parsial terdapat pengaruh yang signifikan antara influencer terhadap Minat Beli dengan tingkat pengaruh yang "Kuat" dan arah hubungan yang positif. Hal tersebut dapat dilihat berdasarkan tabulasi data Uji t dengan nilai tHitung sebesar 9,871 dan tTabel sebesar 1,976. Dengan demikian maka tHitung 9,871 > tTabel 1,976 dengan signifikansi $0,000<0,05$ maka dari itu $\mathrm{H} 0$ ditolak dan Ha diterima.

6. Secara simultan Content Marketing dan Influencer berpengaruh signifikan terhadap Minat Beli konsumen pada Produk Puru Kambera dengan tingat pengaruh yang "Kuat" dan arah hubungan yang positif. Hal tersebut dapat dilihat berdasarkan tabulasi data Uji$F$ dengan nilai $F_{\text {hitung }}$ sebesar 77,029 dan $F_{\text {tabel }}$ sebesar 3,06. Dengan demikian, maka $F_{\text {hitung }}$ 77,209 $>\mathrm{F}_{\text {tabel }}$ 3,06 dengan signifikansi 0,000 < 0,05 maka H0 ditolak dan Ha diterima.

\section{Daftar Pustaka}

[1] Andrews, J. C., \& Shimp , T. A. (2018). Advertising, Promotion and Other Aspect of Integrated Marketing Communication 10th Edition. USA Amerika: Cengage Learning.

[2] Chaffey, D., \& Chadwick, F. E. (2016). Digital Marketing: Strategy, Implementation and practice (6th ed.). London : Pearson.

[3] Hariyanti, N. T., \& Wirapraja, A. (2018). Pengaruh Influencer Marketing Sebagai Srategi Pemasaran Digital Era Modern (Sebuah Studi Literatur). Jurnal Eksekutif Volume 15.

[4] Kotler, P., \& Keller, K. L. (2016). Marketing Management, 15th Edition. England: Pearson Education.

[5] Lammenett, E. (2019). Praxiswissen Online-Marketing. German: SpringerGabler. 